\title{
Effects of Chronic Stretching on Soleus Muscle of Wistar Female Rats
}

\author{
Efectos del Estiramiento Crónico en el Músculo sóleo de Ratas Hembras Wistar
}

Kátia Janine Veiga Massenz; Talita Gianello Gnoato Zotz²; Hilana Rickli Fiuza Martins ${ }^{1,3}$; Talita Mirele Campos²; Nayara Bertoncini² $^{2}$ Luiz Guilherme A. Capriglione ${ }^{4}$; Lúcia Noronha ${ }^{5}$; Marina Luise Viola De Azevedo ${ }^{6}$ \& Anna Raquel Silveira Gomes ${ }^{2,7}$

MASSENZ, K. J. V.; ZOTZ, T. G. G.; MARTINS, H. R. F.; CAMPOS, T. M.; BERTONCINI, N.; CAPRIGLIONE, L. G. A.; NORONHA, L.; AZEVEDO, M. L. V. \& GOMES, A. R. S . Effects of chronic stretching on soleus muscle of Wistar female rats. Int. J. Morphol., 38(4):1039-1046, 2020.

SUMMARY: The purpose of this study was to evaluate the chronic effects of stretching exercise on soleus muscle histomorphology and histomorphometry of young and aged rats. Thirty-eight female rats were divided into young control group (YCG, n=10;274 $\pm 50 \mathrm{~g}) ; \mathrm{young}$ stretching group (YSG, $\mathrm{n}=8 ; 274 \pm 12 \mathrm{~g}$ ); aged control group ( $\mathrm{ACG}, \mathrm{n}=10 ; 335 \pm 39 \mathrm{~g}$ ); and aged stretching group (ASG, $\mathrm{n}=10 ; 321 \pm 32 \mathrm{~g}$ ). A mechanical apparatus was used to stretch muscle in 4 repetitions, $60 \mathrm{~s}$ each, $30 \mathrm{~s}$ interval between repetitions in each session, 3 times a week for 3 weeks. Twenty-four hours after the last stretching session, soleus muscle was removed for micromorphology and immunostaining analysis. Data analyses were performed with one-way ANOVA, post-hoc Tukey, or Kruskal-Wallis tests for parametric and nonparametric, respectively ( $\mathrm{p} \leq 0.05)$. Muscle fiber cross-sectional area (MFCSA) of ACG was lower (18\%) compared to the YCG. Stretching increased MFCSA comparing YSG to YCG $\left(5,681.15 \pm 1,943.61 \mu \mathrm{m}^{2}\right.$ vs $\left.5,119.84 \pm 1,857.73 \mu \mathrm{m}^{2}, \mathrm{p}=0.00\right)$, but decreased comparing ASG to ACG $\left(3,919.54 \pm 1,694.65 \mu \mathrm{m}^{2}\right.$ vs $\left.4,172.82 \pm 1,446.08 \mu \mathrm{m}^{2}, \mathrm{p}=0.00\right)$. More serial sarcomere numbers were found in the YSG than YCG $(12,062.91 \pm 1,564.68$ vs $10,070.39 \pm 1,072.38, \mathrm{p}=0.03)$. Collagen I and collagen III were higher in YSG than ASG $(7.44 \pm 7.18 \%$ vs $0.07 \pm 0.09 \%$, p=0.04) and (14.37 \% \pm $9.54 \%$ vs $5.51 \% \pm 5.52 \%, \mathrm{p}=0.00)$, respectively. TNF-a was greater in ASG than YSG $(43.42 \% \pm 40.19 \%$ vs $1.72 \pm 2.02 \%$, p=0.00). Epimysium was larger in the YSG compared to YCG $(201.83 \pm 132.07 \%$ vs $181.09 \pm 147.04 \%, \mathrm{p}=0.00)$. After 3-week stretching the soleus muscles from aged rats were smaller than their younger counter-parts. Interestingly, while stretching appeared to positively affect young soleus muscle, the opposite was detected in the muscle of the aged rats.

KEY WORDS: Aging; Muscle stretching exercise; Cellular mechanotransduction; Muscle plasticity.

\section{INTRODUCTION}

We can divide stretching exercises according their acute and chronic effects. Acute effects are evaluated immediately after the stretching and chronic effects are investigated after regular practice (days, weeks, or months) (Medeiros \& Lima, 2017).

Stretching exercise is largely used in clinical practice with the goal of increasing joint range of motion (ROM) (Nordez et al., 2017). To date, two main theories have been described to explain physiological effects of stretching exercise that contribute to increase ROM: neural and mechanistic theories (Weppler \& Magnusson, 2010). The mechanistic theory argues that stretching exercise modifies the histomorphometric structures of skeletal muscle tissue to increase ROM (Nordez et al.). In this sense, the maximum ROM may be limited by non-muscular structures, as skeletal muscle connective tissue, but the intracellular mechanism in response to stretching still needs to be investigated.

Studies with young male rats showed that stretching exercise induced structural changes that increased muscle volume, muscle fiber cross-sectional area, and serial sarcomere number (Coutinho et al., 2004; Cação-Benedini et al., 2014). Ywazaki et al. (2016) using an aged rat model verified an increase in muscle fiber cross-sectional area and sarcomerogenesis after a six-week chronic stretching protocol.

\footnotetext{
${ }^{1}$ Physical Education Program at Federal University of Paraná (UFPR), Curitiba, Paraná, Brazil.

${ }^{2}$ Prevention and Rehabilitation in Physiotherapy Department, Federal University of Paraná (UFPR). Curitiba, Paraná, Brazil.

${ }^{3}$ Physiotherapy Department. Midwestern Parana State University (Unicentro), Guarapuava - PR, Brazil.

${ }^{4}$ Health Science Program, Pontifical Catholic University of Paraná, Curitiba, Paraná, Brazil.

${ }^{5}$ Pathology Experimental Laboratory, School of Medicine, Pontifical Catholic University of Paraná, Curitiba, Paraná, Brazil.

${ }^{6}$ Experimental Pathology Laboratory at Pontifical Catholic University of Paraná, Curitiba, Paraná, Brazil.Curitiba, Paraná, Brazil.

${ }^{7}$ Masters and Doctorate Programs in Physical Education. Federal University of Paraná (UFPR), Curitiba, Paraná, Brazil.
} 
MASSENZ, K. J. V.; ZOTZ, T. G. G.; MARTINS, H. R. F.; CAMPOS, T. M.; BERTONCINI, N.; CAPRIGLIONE, L. G. A.; NORONHA, L.; AZEVEDO, M. L. V. \& GOMES, A. R. S . Effects of chronic stretching on soleus muscle of Wistar female rats. Int. J. Morphol., 38(4):1039-1046, 2020.

In contrast, Zotz et al. (2016) using aged female rats (26 months old) detected a reduction of muscle fiber cross-sectional area (MFCSA) and no difference in the serial sarcomere number after a one-week stretching protocol. However, it was not found any study reporting the effects of stretching exercise comparing young and aged skeletal muscle.

In humans the effects of stretching on skeletal muscle is usually assessed through ultrasound to evaluate the fascicle length and pennation angle (Freitas \& Mil-Homens, 2015; Freitas et al., 2016). However, this methodology does not allow us to quantify the skeletal muscle connective tissue as epimysium, perimysium, and endomysium, or to count serial sarcomere numbers involved in ROM improvement. Stretching exercise can stimulate cycles of synthesis and degradation of epimysium, perimysium, and endomysium for skeletal muscle remodeling (Wessner et al., 2019). In addition, type I and type III collagens, growth factors such TGF $\beta 1$ and pro-inflammatory factors as TNF- $\alpha$, can act as signaling cellular pathways to adapt young and aged skeletal muscle (Kusko et al., 2012).

Skeletal muscle fibrosis might be regulated by TNF-a, TGF- $\beta$, and type I and III collagens (Kusko et al.). In aging, TNF- $\alpha$ can positively regulate NF- $\mathrm{kB}$, increasing inflammatory response and contributing to cellular apoptosis and inhibiting MyoD and Mef2 pathways, which might reduce muscle mass and stimulate matrix degradation (Brzeszczynska et al., 2018). In contrast, TNF- $\alpha$ can regulate positively muscle trophysm in young cells' microenvironment, but it is still not known what mechanisms are involved in longitudinal and radial growth after chronic stretching (Farup et al., 2015).

The mechanisms involved in skeletal muscle adaptation after a chronic stretching protocol, both in young and in aged, are poorly understood. Considering that skeletal muscle and connective tissue react to stretching exercise via mechanotransduction, it is important to investigate proteins and factors involved in the signaling pathways to explain mechanistic theory. Thus, the objective of this study was to evaluate the chronic effects of stretching exercise on soleus muscle histomorphology and histomorphometry of young and aged female rats.

\section{MATERIAL AND METHOD}

Animal care and Experimental design: This study was carried out with female Wistar rats in accordance with the international ethics standard for animal experiments and approved by the Ethics Committee on Animal Use of PUCPR (992/2015). This study used young female rats (3 months old) and aged female rats (26 months old). The age of rats was chosen as described by Andreollo et al. (2012). They were kept in the bioterium in standard plastic cages under controlled environmental conditions (luminosity: bright/dark,12-hour cycles) with free access to food pellets and water. All rats presented uniform body weight, were disease free, and came from an inbred strain.

Thirty-eight female rats were divided into 4 groups: young control group (YCG, $\mathrm{n}=10$ ), young stretching group (YSC, $\mathrm{n}=8$ ) aged control group ( $\mathrm{ACG}, \mathrm{n}=10)$, and aged stretching group (ASG, $n=10$ ). Over three weeks, there were losses in the aged control and aged stretching groups because of cardiac respiratory descompensations during the execution of the stretching exercise protocol. Seven aged control rats and 7 aged stretching rats remained for the statistical analyses. All the rats were euthanatized after the three-week experiment period.

Stretching protocol: For mechanical passive static stretching of the left soleus muscle, the rat was weighed (Mettler/Toledo scales, Curitiba, Paraná), and anaesthetized by intraperitoneal injection of $60 \mathrm{mg} / \mathrm{kg}$ ketamine and $5 \mathrm{mg} / \mathrm{kg}$ xylazine. Then, the rat was positioned on the stretching apparatus (Zotz et al., 2019 ) with the tibiotarsal joint in maximum dorsal flexion to stretch the soleus muscle. The stretching protocol consisted of a set of 4 repetitions of 1 minute each with a $30 \mathrm{~s}$ (Zotz et al., 2016) interval between each repetition. The stretching protocol was carried out once a day in the afternoon, three times a week (Monday, Wednesday, and Friday) for three weeks. The control groups were also anaesthetized and positioned on the stretching apparatus to be subjected to the same handling time and recovery similar to stretching group bu without stretching soleus muscle.

Euthanasia of the animals and muscle dissection: The animals were anesthetized by intramuscular injection $(80 \mathrm{mg} /$ $\mathrm{kg}$ ketamine and $8 \mathrm{mg} / \mathrm{kg}$ xylazine) for dissection of the left soleus muscle. Afterwards, while still anesthetized, the rats were euthanized by inducing intracardiac injection with 240 $\mathrm{mg} / \mathrm{kg}$ ketamine and $24 \mathrm{mg} / \mathrm{kg}$ xylazine, according to the ethical principles in animal research. During dissection, the soleus muscle was periodically wetted with saline solution $(0.9 \% \mathrm{NaCl})$ to prevent tissue dryness. After dissection, the soleus muscle was weighed on a precision analytical scale (Mettler/Toledo) and then positioned on a plane surface (Styrofoam) to measure the muscle length using a caliper rule (Vonder). The soleus was divided longitudinally into two equal parts with a blade (Feather). The medial portion of the soleus muscle of each animal was cut crosswise into two equal parts; the proximal portion was destined for an immunohistochemical analysis and muscle fiber cross-sectional area measurements, while the distal portion was destined for counting the serial sarcomere number. 
MASSENZ, K. J. V.; ZOTZ, T. G. G.; MARTINS, H. R. F.; CAMPOS, T. M.; BERTONCINI, N.; CAPRIGLIONE, L. G. A.; NORONHA, L.; AZEVEDO, M. L. V. \& GOMES, A. R. S . Effects of chronic stretching on soleus muscle of Wistar female rats. Int. J. Morphol., 38(4):1039-1046, 2020.

Procedure for Counting the Serial Sarcomere Number: The sarcomere number within a single muscle fiber was determined as described by (Williams \& Goldspink, 1971). The serial sarcomere number was counted using a light microscope (Olympus BX50) and photographed in digital camera (Sony CCD IRIS Camera) with $100 \times$ immersion objective, throughout $300 \mu \mathrm{m}$ of each muscle fiber. The total serial sarcomere number and the length of the sarcomeres in each muscle fiber were estimated by correlation between the number of sarcomeres identified in 3 fields of $100 \mu \mathrm{m}$ fields, totalizing $300 \mu \mathrm{m}$ throughout the muscle fiber and total length of the muscle measured through a caliper rule, as described before.

\section{Histomorphology and Histomorphometry Analysis} Procedures: The proximal portion of the soleus muscle was used to evaluate the muscle fiber cross-sectional area (MFCSA) fixed in a $10 \%$ formalin solution, embedded in paraffin, sectioned transversely $(8 \mu \mathrm{m})$ in a microtome (Olympus) and stained with hematoxylin and eosin (HE). Photomicrographs were taken using the ZEISS Axio Scope A1 microscope and Axion Vision SE64 software through the Software Image Pro Plus 4.5. The cross-sectional areas of 100 muscle fibers were measured for each muscle, chosen at random from the region of the muscle belly of the histological section, as described by Zotz et al (2016). The MFCSA was measured using the software ImageJ (1.52a. USA).

Immunohistochemistry: The immuhistochemistry analysis was determined as describe by Zotz et al. (2016). Immunohistochemistry protocol used included to dehydrate and clear before sections were stained using Rabbit Polyclonal Anti-Human Transforming Growth Factor beta1 (1:100), Spring Science, Pleasanton, California, USA; Rabbit Polyclonal Collagen Type I, AB34710 (1:200), Abcam,
Cambridge, MA, USA; Rabbit Polyclonal Collagen Type III, AB7778 (1:200), Abcam, Cambridge, MA, USA; and Mouse Monoclonal Antibody TNFa, sc-52252 (1:100), Santa Cruz Biotechnology, Inc., Heidelberg, Germany.

The slides were photographed using the ZEISS Axio Scope A1 microscope and AxioN Vision SE64 software with the $40 x$ objective with the maximum magnification (400x) to analyze the images. The monochrome mask was carried out as described below to analyze the images. The "mask" was applied and the immunopositive area of each of the antibodies was measured by software Image Pro Plus (4.5 Version, Washington, USA).

The ratio between the proportion of collagen I and collagen III was calculated, considering the average percentage of collagen I as numerator and the average percentage of collagen III as denominator; thus, the control groups were considered as reference values.

\section{Epimysium, Perimysium, and Endomysium Measurement:} To perform the measurement of the epimysium, perimysium, and endomysium, the proximal portion of the soleus muscle was stained with hematoxylin and eosin (HE). Photomicrographs of the slides were made using the light microscope (Olympus BX50) and photographed in digital camera (Sony CCD IRIS Camera) with 20x objective on maximum magnification (200x).

The epimysium and perimysium marking were done using the software Phothosop CS6 Portable (13.0 version, BRA) The structures of the epimysium and perimysium were stained with a dot different colors (green pantone $802 \mathrm{C}$ and orange pantone $715 \mathrm{C}$, respectively, Fig. 1A-B). The

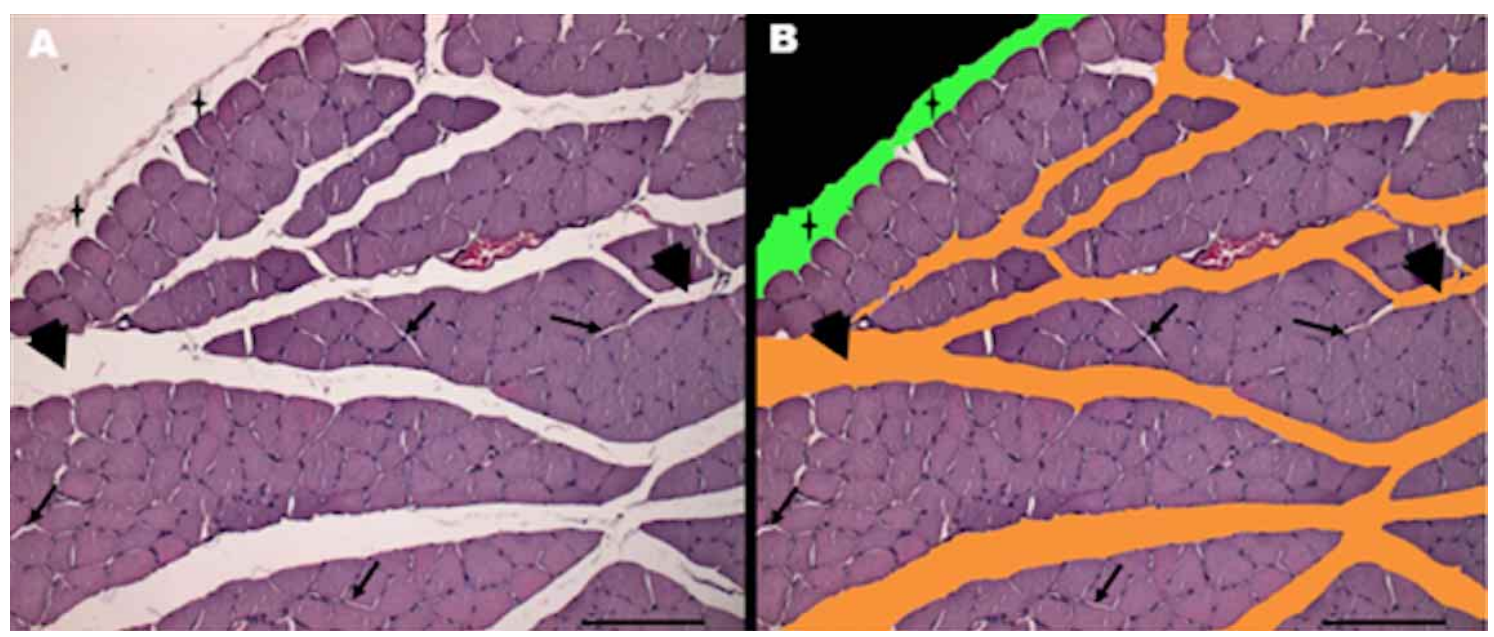

Fig. 1. Cross-sectional photomicrograph of the soleus muscle stained with hematoxylin and eosin (HE), 20x objective. (A) Photomicrography before editing in Photoshop CS6 Portable (version 13.0, BRA). (B) Photomicrograph after epimysium and perimysium marking (green pantone $802 \mathrm{C}$ and orange pantone $715 \mathrm{C}$, respectively) and black background staining. (+) epimysium; (arrowhead) perimysium; (arrows) endomysium. Scale bar: $50 \mu \mathrm{m}$. 
endomysium, connective tissue that surrounds each unit of muscle fiber, was not manually marked. The white background color of the slide was used to craft the mask to measure its area.

Two independent examiners analyzed 5 identical photomicrographs, considering the following criteria: epimysium (external portion involving the entire muscle bundle) and perimysium (portions of connective tissue involving a bundle of muscle fibers), then the intraclass correlation coefficient (ICC) was calculated inter evaluators. There was a strong agreement of $87 \%$ for epimysium ($0.22 / 0.98, \mathrm{SEM}=0.36$ ) and $97 \%$ for perimysium measurements between the evaluators $(0.72 / 0.99$, $\mathrm{SEM}=0.17$ ). Afterwards only one evaluator carried out the epimysium, perimysium, and endomysium measurements. For application of the mask, the background color of the slide itself was considered, that is, with color. Hereafter, the areas of epimysium, perimysium, and endomysium were marked by the mask and analyzed with Image Pro Plus software.

Statistical Analysis: The Levene and Shapiro-Wilk tests were applied to test homogeneity and normality, respectively. When normality was identified the comparisons between groups were made by the analysis of variance (ANOVA oneway post-hoc Tukey). For non-parametric results, the Independent Samples Kruskal-Wallis test was used for between groups comparison. All results are reported as the mean \pm standard deviation.
The relative difference $(\%)$ of measurements between the stretching groups and the control groups was calculated using the equation $[(\mathrm{A}-\mathrm{B} / \mathrm{B}) \times 100]$, the following groups were chosen: (A) stretching group and (B) control group. When comparing the stretching groups, the value inserted in A depended on the relative comparison that was to be applied. All the analyses were carried out using the SPSS software (version 20.0®), considering a significance level of $95 \%(\mathrm{p}<0.05)$.

\section{RESULTS}

The average force needed to stretch aged muscle was greater when compared to the force applied in youngs over 3 weeks $(0.91 \pm 0.10$ vs $0.75 \pm 0.06, p=0.00$, Kruskal-Wallis test $)$.

Table I shows the animal body mass and muscle mass data. All the groups except the YCG reduced body mass after 3 weeks, but the percentage of body mass reduction was not different among the groups.

Regarding MFCSA, the ACG presented $18 \%$ lower when compared to the YCG. However, MFCSA increased 11 $\%$ in the YSG compared to YCG. In contrast, the MFCSA decreased $6 \%$ in ASG compared to ACG. MFCSA in the ASG was $31 \%$ lower compared to YSG. These results are presented in Table II.

Table I. Body and muscle mass.

\begin{tabular}{cccccc}
\hline Groups & Inicial Body Mass (g) & Final Body Mass (g) & $\begin{array}{c}\text { Body Mass } \\
\text { Reduction } \\
\%\end{array}$ & $\begin{array}{c}\text { Final Muscle } \\
\text { Mass (g) }\end{array}$ & $\begin{array}{c}\text { Muscle Mass Relative to } \\
\text { Final Body Mass ( \%) }\end{array}$ \\
\hline YCG & $300.00 \pm 43.05$ & $274.50 \pm 22.35$ & $3 \%$ & $0.14 \pm 0.02$ & $0.05 \pm 0.00$ \\
YSG & $270.87 \pm 19.45$ & $253.75 \pm 12.42^{*}$ & $5 \%$ & $0.16 \pm 0.02$ & $0.06 \pm 0.00$ \\
ACG & $356.57 \pm 41.91$ & $335.28 \pm 39.76^{*}$ & $6 \%$ & $0.14 \pm 0.03$ & $0.04 \pm 0.00 \%$ \\
ASG & $344.28 \pm 39.70$ & $321.42 \pm 32.67^{*}$ & $6 \%$ & $0.14 \pm 0.06$ & $0.04 \pm 0.02$ \\
\hline
\end{tabular}

YCG, young control group; YSG, young stretching group; ACG, aged control group; ASG, aged stretching group. ${ }^{\text {a }}$ Body mass reduction comparing final to initial body mass $(\mathrm{p}>0.05)$. The results are described as mean \pm standard deviation. $* 0.01$ (Paired $\mathrm{t}$-test) in relation to initial body mass. ${ }^{\bullet} 0.00$ (ANOVA one-way Post-Hoc Tukey) in comparison to YCG. $\$ 0.00$ (ANOVA one-way Post-Hoc Tukey) in comparison to YSG. †0.00 (Kruskal-Wallis test) in comparison to YSG. " 0.00 (Kruskal-Wallis test) in comparison to YSG.

Table II. Effects of chronic stretching exercise on the soleus histomorphometry of young and aged rats.

\begin{tabular}{llllc}
\hline Groups & MFCSA $\left(\mu \mathrm{m}^{2}\right)$ & $\begin{array}{c}\text { Muscle Length } \\
(\mathrm{mm})\end{array}$ & $\begin{array}{c}\text { Serial Sarcomere } \\
\text { Number }(\mu \mathrm{m})\end{array}$ & $\begin{array}{c}\text { Sarcomere Length } \\
(\mu \mathrm{m})\end{array}$ \\
\hline YCG & $5,119.84 \pm 1,857.73$ & $22.34 \pm 1.58$ & $10,070.39 \pm 1,072.38$ & $2.23 \pm 0.26$ \\
YSG & $5,681.15 \pm 1,943.61^{*}$ & $22.07 \pm 1.55$ & $12,062.91 \pm 1,564.68^{\star \star}$ & $1.85 \pm 0.20^{\ddagger}$ \\
ACG & $4,172.82 \pm 1,446.08^{-}$ & $22.14 \pm 2.56$ & $10,959.38 \pm 1,150.31$ & $2.02 \pm 0.16$ \\
ASG & $3,919.54 \pm 1,694.65^{\# \dagger}$ & $25.12 \pm 2.46^{\text {Iः }}$ & $11,475.42 \pm 2,048.29$ & $2.24 \pm 0.38^{\star}$
\end{tabular}

YCG, young control group; YSG, Young stretching group; ACG, aged control group; ASG, aged stretching group. The results are described as mean \pm standard deviation. *0.00 (Kruskal-Wallis test) compared to YCG. ${ }^{*} 0.00$ (Kruskal-Wallis test) compared to YCG. "0.03 (Kruskal-Wallis test) in comparison to ACG. $† 0.00$ (Kruskal-Wallis test) compared to YSG. ${ }^{\text {II }} 0.04$ (ANOVA one-way Post-Hoc Tukey test) when compared to ACG. $\$ 0.03$ (ANOVA one-way Post-Hoc Tukey test) compared to YSG. ${ }^{* *} 0.03$ (ANOVA one-way Post-Hoc Tukey) compared to YCG. ${ }^{\ddagger} 0.00$ (Kruskal-Wallis test) compared to YCG. ${ }^{\bullet} 0.02$ (Kruskal-Wallis test) compared to YSG. 
For muscle length, serial sarcomere number and sarcomere length, ASG muscle length was $13 \%$ longer in comparison to ACG and $14 \%$ lengthier than YSG. A higher serial sarcomere number was detected in the YSG than YCG and the sarcomere length was $17 \%$ shorter in YSG compared to YCG and $10 \%$ longer in ASG than ACG (Table II).
For immunohistochemistry analisys, the areas of collagen type I, type III, TGF-b1, and TNF-a are expressed as percentage in relation to the muscle fiber area in each photomicrograph. The data are presented in Table III.

The amount of epimysium, perimysium, and endomysium is expressed as percentages in relation to the muscle fiber area in each photomicrography. See Table IV.

Table III. Effects of chronic stretching exercise on the soleus immunohistochemistry of young and aged rats.

\begin{tabular}{lccccc}
\hline Groups & $\begin{array}{c}\text { Collagen } \\
\text { Type I }(\%)\end{array}$ & $\begin{array}{c}\text { Collagen } \\
\text { Type III }(\%)\end{array}$ & $\begin{array}{c}\text { Ratio Col I: } \\
\text { Col III }\end{array}$ & $\begin{array}{c}\text { TGF-31 } \\
(\%)\end{array}$ & $\begin{array}{c}\text { TNF- } \alpha \\
(\%)\end{array}$ \\
\hline YCG & $1.42 \pm 2.92$ & $13.61 \pm 10.24$ & $0.11 \pm 0.18$ & $2.97 \pm 3.91$ & $0.30 \pm 0.39$ \\
YSG & $7.44 \pm 7.18^{*}$ & $14.37 \pm 9.54$ & $0.88 \pm 1.35^{\# \Pi}$ & $10.68 \pm 12.73$ & $1.72 \pm 2.02 \pi$ \\
ACG & $0.56 \pm 0.68$ & $13.14 \pm 13.77$ & $0.14 \pm 0.26$ & $3.89 \pm 7.37$ & $26.29 \pm 22.98 *$ \\
ASG & $0.07 \pm 0.09^{\# \dagger}$ & $5.51 \pm 5.52 *^{*}$ & $0.02 \pm 0.03$ & $5.91 \pm 10.36$ & $43.42 \pm 40.19 \%$ \\
\hline
\end{tabular}

YCG, young control group; YSG, Young stretching group; ACG, aged control group; ASG, aged stretching group. *0.00 (KruskalWallis test) in relation to YCG. \#0.04 (Kruskal-Wallis test) in relation to ACG. $\dagger 0.00$ (Kruskal-Wallis test) in relation to YSG. ${ }^{¥} 0.00$ (Kruskal-Wallis test) in relation to YSG. " 0.00 (Kruskal-Wallis test) in relation to the ACG. " 0.00 (Kruskal-Wallis test) in relation to YCG. " 0.00 (Kruskal-Wallis test) in relation to the ACG. ${ }^{+} 0.00$ (Kruskal-Wallis tests) in relation to YCG. $\beta 0.00$ (Kruskal-Wallis test) in relation to YCG. $\ddagger 0,00$ (Kruskal-Wallis tests) in relation to YSG.

Table IV. Effect of chronic stretching exercise on the connective tissue area of young and aged rats.

\begin{tabular}{cccc}
\hline Groups & \multicolumn{1}{c}{$\begin{array}{c}\text { Epimysium } \\
(\%)\end{array}$} & $\begin{array}{c}\text { Perimysium } \\
(\%)\end{array}$ & $\begin{array}{c}\text { Endomysium } \\
(\%)\end{array}$ \\
\hline YCG & $83.19 \pm 116.14$ & $181.09 \pm 147.04$ & $66.64 \pm 46.40$ \\
YSG & $30.52 \pm 18.37$ & $201.83 \pm 132.07 \#$ & $34.68 \pm 30.23$ \\
ACG & $14.04 \pm 6.51^{*}$ & $84.30 \pm 36.84^{\dagger}$ & $17.49 \pm 12.03^{*}$ \\
ASG & $16.81 \pm 13.74$ & $83.98 \pm 63.43$ & $30.17 \pm 26.89$ \\
\hline
\end{tabular}

YCG, young control group; YSG, Young stretching group; ACG, aged control group; ASG, aged stretching group. *0.00 (Kruskal-Wallis test), in relation to YCG. \#0.01 (Kruskal-Wallis test) in relation to ACG. $\dagger 0.00$ (Kruskal-Wallis test) in relation to YCG. $\ddagger 0.00$ (Kruskal-Wallis test) in relation to YCG.

\section{DISCUSSION}

The main finding of this study was to detect MFCSA reduction in aged soleus muscle when compared to young ones, indicating sarcopenia. Even when the aged absolute final body mass was superior than younger muscles and nondifference was found in the muscle mass, the MFCSA of aged was $18 \%$ lower than young control rats. The TNF- $\alpha$ should have contributed to this because of its higher percentage compared to young control rats. Chronic systemic inflammation known as inflammaging is characterized by high levels of TNF- $\alpha$, which triggers a cascade of sarcomeric protein degradation, positively regulating $\mathrm{NF}-\mathrm{kB}$, which stimulates proteins such as p53, Foxo and p38, activating MAPK kinase pathway resulting in muscle atrophy (Bonaldo \& Sandri, 2013).
In contrast, young soleus muscle stretched showed hypertrophy, sarcomerogenesis, and increase collagen type I, what may be evidencieded wich rise collagen I:III ratio and further to greater perimysium area found in young muscle. However, TNF-a also increased in young stretched muscle. Thus, these findings can indicate that TNF-a triggers multiple cell responses, depending on the cellular microenvironment activating different pathways, i.e., aged showed atrophy effect while young showed hypertrophic effect.

The increase of MFCSA in young rats accompanied by a rise in the TNF- $\alpha$ immunostain might have activated NF-kB within myoblasts, resulting in cyclin D1 upregulation enhancing muscle mass by Akt/Mtor (Saini et al., 2016). Studies with young male rats have shown that 15 minutes of static stretching exercise carried out twice a week for 2 weeks was effective in reversing soleus muscle atrophy caused by denervation. The authors attributed the finding to the activation of $\mathrm{Akt} / \mathrm{MtOR} / \mathrm{p} 70 \mathrm{~s} 6 \mathrm{k}$ pathway suppressing muscle degeneration (Agata et al., 2009).

Aged stretching muscle showed hypotrophy and a decrease of both types of collagens. Although TNF- $\alpha$ has contributed to both serial and parallel hypertrophy in youngsters, it induced atrophy in the aged muscle. Nevertheless, the magnitude of atrophy after 3 weeks $(6 \%)$ was smaller when compared to Zotz et al. (2016) that reported $21 \%$ MFCSA decrease after one week of stretching. These findings suggest that chronic stretching ( 3 weeks) was better than acute ( 1 week) for skeletal muscle trophysm of aged. We could hypothesize that hypotrophy induced through 
MASSENZ, K. J. V.; ZOTZ, T. G. G.; MARTINS, H. R. F.; CAMPOS, T. M.; BERTONCINI, N.; CAPRIGLIONE, L. G. A.; NORONHA, L.; AZEVEDO, M. L. V. \& GOMES, A. R. S . Effects of chronic stretching on soleus muscle of Wistar female rats. Int. J. Morphol., 38(4):1039-1046, 2020.

stretching in aged muscle is time dependent because when applied over 3 weeks, the decrease was much less than acute effect after one week. We recommend for future studies to investigate the time course effect after 2 and 4 weeks of stretching to elucidate the mechanisms involved in the regulation of muscle trophysm.

Another study carried out manual stretching, 10 repetitions of 30 s each, i.e., 600 s volume per session on shortened soleus muscle of young male rats, 3 times per week for 3 weeks. The study showed $10 \%$ increase in MFCSA (Coutinho et al., 2006). In this study, augment of MFCSA in young female rats after intermittent stretching protocol, carried out 4 repetitions of one minute, 3 times a week, for 3 weeks. Thus, the hypertrophy less pronounced in female rats than male rats could be explained by the shorter stretching time applied in female rats and or due to the hormone differences between the sexes.

Young female rats showed an increase in serial sarcomere number and a decrease in sarcomere length. Another study carried out intermittent manual stretching, 10 repetitions of $30 \mathrm{~s}$ each, i.e., $300 \mathrm{~s}$ volume per session, on shortened soleus muscle of young female rats, for 3 days. This resulted in a $32 \%$ increase in sarcomere number without modification in sarcomere length (Coutinho et al., 2006). Moreover, a protocol of 10 repetitions of $60 \mathrm{~s}$ each, i.e., 600 $\mathrm{s}$ volume per session, on soleus muscle of young female rats, but ovariectomized and hysterectomized, for 12 days, resulted in a $25 \%$ increase in sarcomere number without modification in sarcomere length (Ywazaki et al.).

In this study, the stretching protocol resulted in a 20 $\%$ increase in sarcomere number without modification in sarcomere length. It was verified that a smaller volume of daily stretching, performed for a longer period, promoted sarcomerogenesis in muscles that were not previously immobilized, demonstrating the benefits of chronic stretching exercise in youngsters. Although was found longer muscle length, no difference in serial sarcomeres and lengthier sarcomeres was found in aged stretched muscle. Stretching can increase skeletal muscle in both longitudinal and radial directions but it is not known how a cell gets larger or smaller, longer or shortened, mainly in aged (Freitas et al.). Another study compared 24-month-old and 6-month-old mice and found in older mice that tendons were $31 \%$ longer than in young mice (Nielsen et al., 2018). In this sense, tendon length could have contributed to increased muscle length.

In the young stretching group, there was an increase in collagen type I, accompanied by higher deposition of connective tissue in the perimysium. Collagen biosynthesis is characterized by the presence of an extensive amount of post-translational factors of polypeptide chains, which contribute to the quality and stability of the collagen molecule in the ECM. The response depends on the external force for its modulation, such as the stretching exercise (CaçãoBenedini et al., 2013). According to Kjaer et al. (2004) the demand for connective tissue is also controlled by passive force. Greater cross-sectional area of muscle fiber could imply greater passive force generation; thus, we hypothesized that the increase in the deposition of type I collagen and increase of the perimysium may have occurred due to the greater tensile strength.

This fact may have a relation between strength and activation of integrin receptors as demonstrated by Kjaer $e t$ $a l$. the greater tensile force in the extremities of young fibroblasts and the greater myofibrillar response demonstrate the interference of external mechanical load and the ECM condition in the tissue deformation. Thus, it is suggested that in young rats, a higher level of TNF- $\alpha$ may put forward positive regulation of muscle mass.

In the aged control group, a lower percentage of epimysium, endomysium, and perimysium was evidenced, suggesting topographic reorganization of connective tissue due to the aging process. During the aging, concomitant reduction of the synthesis of collagen is verified by the increase of the degradation of the ECM due to the inflamed microenvironment. Durotraxis is the response to mechanical stiffness, which may include induction of connective tissue deposition or action of metalloproteinases, depending on the cellular environment (Kragstrup et al., 2011). Hence, considering the process of inflammaging in aged mice, we could hypothesize that ECM degradation and stretching exercise was not effective due to inefficiency of mechanical force transmission.

According to Zotz et al. (2016) acute effect of stretching in the soleus muscle of aged rats, applied in a volume of $240 \mathrm{~s}$ ( 4 repetitions of $60 \mathrm{~s}$ ), 3 times a week for 1 week, showed an antifibrotic effect demonstrated by an increase in type III collagen and a decrease in type I collagen and TGF $\beta-1$. However, our findings showed that chronic stretching, applied for 3 weeks, decreased both collagen types and no changes in TGF $\beta-1$ in the aged stretching group. This data could be explained because activation of TGF- $\beta$ occurs $48 \mathrm{~h}$ after eccentric exercise and soleus muscle was collected $24 \mathrm{~h}$ after the last stretching session (Smith et al., 2007).

The present study has limitations: (1) functional evaluations were not performed, such as muscle strength and gait; (2) connective tissue arrangement was not analyzed; (3) molecular analysis was not performed and could help to clarify signaling pathways. 


\section{CONCLUSION}

After 3-week stretching protocol soleus muscle from aged rats were smaller than their younger counter-parts. Interestingly, while stretching appeared to positively affect young soleus muscle, the opposite was detected in the muscle of the aged rats.

\section{ACKNOWLEDGEMENTS}

The authors are grateful to the Federal University of Paraná; Pontificia Universidade Católica do Paraná (PUC/ PR, Curitiba-PR); National Council for Scientific and TechnologicalDevelopment (CNPq) and Fundação Araucária. This studywas financed in part by the Coordenacão de Aperfeicoamento de Pessoal de NívelSuperior - Brasil (CAPES) - Finance Code 001. We are thankful to Rafael Zotz for the technical assistance.

MASSENZ, K. J. V.; ZOTZ, T. G. G.; MARTINS, H. R. F.; CAMPOS, T. M.; BERTONCINI, N.; CAPRIGLIONE, L. G. A.; NORONHA, L.; AZEVEDO, M. L. V. \& GOMES, A. R. S. Efectos del estiramiento crónico en el músculo sóleo de ratas hembras Wistar. Int. J. Morphol., 38(4):1039-1046, 2020

RESUMEN: El propósito de este estudio fue evaluar los efectos crónicos del ejercicio de estiramiento sobre la histomorfología e histomorfometría del músculo sóleo de ratas jóvenes y envejecidas. Se dividieron 38 ratas hembras en un grupo control joven (YCG, $\mathrm{n}=10 ; 274 \pm 50 \mathrm{~g}$ ); grupo de estiramiento joven (YSG, $n=8 ; 274 \pm 12 \mathrm{~g}$ ); grupo control de edad (ACG, $n=$ $10 ; 335 \pm 39 \mathrm{~g}$ ); y grupo estiramiento envejecido (ASG, $\mathrm{n}=10$; $321 \pm 32 \mathrm{~g}$ ). Se usó un aparato mecánico para estirar el músculo en 4 repeticiones, $60 \mathrm{~s}$ cada una, intervalo de $30 \mathrm{~s}$ entre repeticiones en cada sesión, 3 veces por semana, durante 3 semanas. Veinticuatro horas después de la última sesión de estiramiento, se extrajo el músculo sóleo para análisis de micromorfología e inmunotinción. Los análisis de datos se realizaron con pruebas ANOVA de una vía, Tukey post-hoc o Kruskal-Wallis para pruebas paramétricas y no paramétricas, respectivamente $(\mathrm{p} \leq 0,05)$. El área de la sección transversal de fibra muscular (MFCSA) de GCE fue menor (18\%) en comparación con el GCJ. El estiramiento aumentó ASTFM comparando GEJ con GCJ $\left(5.681,15 \pm 1.943,61 \mu \mathrm{m}^{2}\right.$ vs $5.119,84 \pm$ $1.857,73 \mu \mathrm{m}^{2}, \mathrm{p}=0,00$ ), pero disminuyó comparando GEE con $\operatorname{GCE}\left(3.919,54 \pm 1.694,65 \mu \mathrm{m}^{2}\right.$ vs $4.172,82 \pm 1.446,08 \mu \mathrm{m}^{2}, \mathrm{p}=$ $0,00)$. Se encontraron más sarcómeros en serie en el GEJ que en el $\operatorname{GCJ}(12.062,91 \pm 1.564,68$ vs $10.070,39 \pm 1,072.38, p=0,03)$. El colágeno I y el colágeno III fueron más numerosos en GEJ que en $\operatorname{GEE}(7,44 \pm 7.18 \%$ vs $0,07 \pm 0,09 \%, \mathrm{p}=0,04)$ y $(14,37 \% \pm 9,54$ $\%$ vs $5,51 \% \pm 5,52 \%, p=0,00)$, respectivamente. TNF- $\alpha$ fue mayor en GEE que GEJ $(43,42 \% \pm 40,19 \%$ vs $1,72 \pm 2,02 \%$, p = $0,00)$. El epimisio fue mayor en el GEJ en comparación con el
GCJ $(201,83 \pm 132,07 \%$ vs $181,09 \pm 147,04 \%, p=0,00)$. Después de 3 semanas de estiramiento, los músculos sóleo de las ratas envejecidas eran más pequeños que sus contrapartes más jóvenes. Curiosamente, si bien el estiramiento pareció afectar positivamente el músculo sóleo joven, se detectó lo contrario en el músculo de las ratas envejecidas.

PALABRAS ClAVE: Envejecimiento; Ejercicio de estiramiento muscular; Mecanotransducción celular; Plasticidad muscular.

\section{REFERENCES}

Agata, N.; Sasai, N.; Inoue-Miyazu, M.; Kawakami, K.; Hayakawa, K.; Kobayashi, K. \& Sokabe, M. Repetitive stretch suppresses denervation-induced atrophy of soleus muscle in rats. Muscle Nerve, 39(4):456-62, 2009.

Andreollo, N. A.; dos Santos, E. F.; Araújo, M. R. \& Lopes, L. R. Rat's age versus human's age: what is the relationship? ABCD Arq. Bras. Cir. Dig., 25(1):49-51, 2012.

Bonaldo, P. \& Sandri, M. Cellular and molecular mechanisms of muscle atrophy. Dis. Model. Mech., 6(1):25-39, 2013.

Brzeszczynska, J.; Meyer, A.; McGregor, R.; Schilb, A.; Degen, S.; Tadini, V.; Johns, N.; Langen, R.; Schols, A.; Glass, D. J.; et al. Alterations in the in vitro and in vivo regulation of muscle regeneration in healthy ageing and the influence of sarcopenia. $J$. Cachexia Sarcopenia Muscle, 9(1):93-105, 2018.

Cação-Benedini, L. O.; Ribeiro, P. G.; Gomes, A. R.; Ywazaki, J. L.; Monte-Raso, V. V.; Prado, C. M. \& Mattiello-Sverzut, A. C. Remobilization through stretching improves gait recovery in the rat. Acta Histochem., 115(5):460-9, 2013.

Cação-Benedini, L. O.; Ribeiro, P. G.; Prado, C. M.; Chesca, D. L. \& Mattiello-Sverzut, A. C. Immobilization and therapeutic passive stretching generate thickening and increase the expression of laminin and dystrophin in skeletal muscle. Braz. J. Med. Biol. Res., 47(6):483-91, 2014.

Coutinho, E. L.; DeLuca, C.; Salvini, T. F. \& Vidal, B. C. Bouts of passive stretching after immobilization of the rat soleus muscle increase collagen macromolecular organization and muscle fiber area. Connect. Tissue Res., 47(5):278-86, 2006.

Coutinho, E. L.; Gomes, A. R.; França, C. N.; Oishi, J. \& Salvini, T. F. Effect of passive stretching on the immobilized soleus muscle fiber morphology. Braz. J. Med. Biol. Res., 37(12):1853-61, 2004.

Farup, J.; Madaro, L.; Puri, P. L. \& Mikkelsen, U. R. Interactions between muscle stem cells, mesenchymal-derived cells and immune cells in muscle homeostasis, regeneration and disease. Cell Death Dis., 6:e1830, 2015.

Freitas, S. R. \& Mil-Homens, P. Effect of 8-week high-intensity stretching training on biceps femoris architecture. J. Strength Cond. Res., 29(6):1737-40, 2015.

Freitas, S. R.; Vaz, J. R.; Bruno, P. M.; Andrade, R. \& Mil-Homens, P. Stretching effects: High-intensity \& Moderate-duration vs. Lowintensity \& Long-duration. Int. J. Sports Med., 37(3):239-44, 2016.

Kjaer, M. Role of extracellular matrix in adaptation of tendon and skeletal muscle to mechanical loading. Physiol. Rev., 84(2):64998, 2004

Kragstrup, T. W.; Kjaer, M. \& Mackey, A. L. Structural, biochemical, cellular, and functional changes in skeletal muscle extracellular matrix with aging. Scand. J. Med. Sci. Sports, 21(6):749-57, 2011.

Kusko, R. L.; Banerjee, C.; Long, K. K.; Darcy, A.; Otis, J.; Sebastiani, P.; Melov, S.; Tarnopolsky, M.; Bhasin, S. \& Montano, M. Premature 
expression of a muscle fibrosis axis in chronic HIV infection. Skelet. Muscle, 2(1):10, 2012.

Medeiros, D. M. \& Lima, C. S. Influence of chronic stretching on muscle performance: Systematic review. Hum. Mov. Sci., 54:220-9, 2017.

Nielsen, K. B.; Lal, N. N. \& Sheard, P. W. Age-related remodelling of the myotendinous junction in the mouse soleus muscle. Exp. Gerontol., 104:52-9, 2018.

Nordez, A.; Gross, R.; Andrade, R.; Le Sant, G.; Freitas, S.; Ellis, R.; McNair, P. J. \& Hug, F. Non-muscular structures can limit the maximal joint range of motion during stretching. Sports Med., 47(10):1925-9, 2017.

Saini, J.; McPhee, J. S.; Al-Dabbagh, S.; Stewart, C. E. \& Al-Shanti, N. Regenerative function of immune system: Modulation of muscle stem cells. Ageing Res. Rev., 27:67-76, 2016.

Smith, C. A.; Stauber, F.; Waters, C.; Always, S. E. \& Stauber, W. T. Transforming growth factor-beta following skeletal muscle strain injury in rats. J. Appl. Physiol., 102(2):755-61, 2007.

Weppler, C. H. \& Magnusson, S. P. Increasing muscle extensibility: a matter of increasing length of modifying sensation? Phys. Ther., 90:438-49, 2010.

Wessner, B.; Liebensteiner, M.; Nachbauer, W. \& Csapo, R. Age-specific response of skeletal muscle extracellular matrix to acute resistance exercise: A pilot study. Eur. J. Sport Sci., 19(3):354-64, 2019.

Williams, P. E. \& Goldspink, G. Longitudinal growth of striated muscle fibres. J. Cell Sci., 9(3):751-67, 1971.

Ywazaki, J. L.; Loureiro, A. P. C.; Zotz, T. G. G.; Nascimento, L. R.; Nobre, D. V. \& Gomes, A. R. S. Effects of resistive exercise and stretching on the soleus muscle of ovariectomized rats. Fisioter. Pesqui., 23(1):7483, 2016.

Zotz, T. G. G.; Zotz, R.; Guimarães, A. T. B.; Goossen, E. Gomes, A. R. S. The development of a mechanical device to stretch skeletal muscle of young and old rats. Clinics (Sao Paulo), 74:e629, 2019.

Zotz, T. G.; Capriglione, L. G.; Zotz, R.; Noronha, L.; Viola De Azevedo, M. L.; Fiuza Martins, H. R. \& Silveira Gomes, A. R. Acute effects of stretching exercise on the soleus muscle of female aged rats. Acta Histochem., 118(1):1-9, 2016.
Correspondent author:

Hilana Rickli Fiuza Martins.

Physical Education Program

Federal University of Paraná (UFPR)

Curitiba, Paraná

BRAZIL

Email: hilana_@hotmail.com

Received: 21-11-2019

Accepted: 13-02-2020 